\title{
The effect of internal branding on organisational financial performance and brand loyalty: mediating role of psychological empowerment
}

\author{
Maryam Soleimani
}

Department of Management, Economics and Accounting, Payame Noor University, Tehran, Islamic Republic of Iran

\author{
Leo Paul Dana \\ Dalhousie University, Halifax, Canada
}

Aidin Salamzadeh

Faculty of Management, University of Tehran, Tehran, Islamic Republic of Iran Parisa Bouzari

Department of Supply Chain Management, Faculty of Economics and Social Sciences, Hungarian University of Agriculture and Life Sciences, Godollo, Hungary, and

\section{Pejman Ebrahimi}

Doctoral School of Economic and Regional Sciences, Hungarian University of Agriculture and Life Sciences, Godollo, Hungary

\begin{abstract}
Purpose - This study explores the effect of internal branding on organisational financial performance and brand loyalty with the mediating role of psychological empowerment.

Design/methodology/approach - The data gathered from 200 Pasargad insurance employees in Iran were analysed. Structural Equation Modelling and $R$ were used to evaluate the model. Financial performance was measured by four Concepts (ROI, ROE, Sales growth, ROA) based on available data from March 2010 to March 2020. Findings - The results revealed that internal branding and psychological empowerment have no significant effect on financial performance, but both have a significant positive effect on brand loyalty. Likewise, the mediating role of psychological empowerment on the subject of the impact of internal branding on brand loyalty was confirmed. Furthermore, psychological empowerment did not play a mediating role in the impact of internal branding on financial performance.

Research limitations/implications - The findings of this study could be important for managers of organisations active in the insurance industry to highlight internal branding and enhance psychological empowerment and employee brand loyalty. Moreover, managers' perception of the effective role of psychological empowerment to enhance employee brand loyalty is another practical aspect of this research. Originality/value - Considering the mediating role of psychological empowerment to the effect of internal branding on financial performance and brand loyalty is an innovative aspect of the present study. Meanwhile, the use of $R$ software for VB-SEM was another point to surge the value of this paper.
\end{abstract}

Keywords Internal branding, Psychological empowerment, Financial performance, Brand loyalty

Paper type Research paper

(C) Maryam Soleimani, Leo Paul Dana, Aidin Salamzadeh, Parisa Bouzari and Pejman Ebrahimi. Published in Journal of Asian Business and Economic Studies. Published by Emerald Publishing Limited. This article is published under the Creative Commons Attribution (CC BY 4.0) licence. Anyone may reproduce, distribute, translate and create derivative works of this article (for both commercial and non-commercial purposes), subject to full attribution to the original publication and authors. The full terms of this licence may be seen at http://creativecommons.org/licences/by/4.0/legalcode.
The effect of internal branding

Received 6 August 2021 Revised 1 November 2021 4 December 2021 Accepted 30 December 2021 


\section{Introduction}

Establishing a strong brand and boosting performance are crucial components in maintaining long-term organisational survival (Lee et al., 2008). Branding can be considered a major topic for improving brand positioning and organisational performance. Accordingly, organisations should foster brand supportive behaviour to foster a positive organisational climate and improve employees' shared understanding of brand values (Matanda and Ndubisi, 2013). Branding is a multi-dimensional concept, and when used among employees of an organisation, it is referred to as internal branding (Hasni et al., 2018). Internal branding can be identified as a means of establishing potent brands for the company. Internal branding aims to ensure that brand messages are conveyed to employees by the brand, for customers and other stakeholders (Punjaisri and Wilson, 2017). According to internal branding literature, employees have the role of "brand ambassadors" who need to display the brand meaning through their actions and interactions, thereby helping to foster a consistent brand image among all the stakeholders. Service organisations have found that the brand message conveyed to employees is as important as the message sent to customers. In effect, employees of an organisation are internal customers, and the lack of their support of brand message can undermine brand reputation.

In addition to internal branding, today, psychological empowerment has become very important because of its impact on the beneficial outcomes associated with individuals and organisations. For example, the positive effect of psychological empowerment on job satisfaction (Shah et al., 2019), organisational citizenship behaviour (Chiang and Hsieh, 2012), organisational commitment, task and contextual performance (Seibert et al., 2011) is known. Then, identifying the antecedents and consequences of psychological empowerment is vital for employees to identify effective human resource strategies.

While devoting resources to educating and training employees about mastering the brand message, many service organisations do not prioritise it unless its effects on financial performance are recognised. Those activities that do not directly contribute to the company's financial profit are often the first activities to be reduced (Tuominen et al., 2016). The same is true of employee psychological empowerment. Organisations will prioritise attention to the psychological needs of employees when they realise its relationship to financial performance. On the other hand, brand loyalty, which is considered an employees' brand - supporting behaviours and an intangible and valuable asset-is an important factor for brand performance and can be the focus of managers as a source for achieving competitive advantage and success of organisations especially service organisations.

A review of previous research shows that some studies have confirmed the positive effect of internal branding on financial performance, and other studies (Lee et al., 2008; Tuominen et al., 2016) have reported opposite results. Given the contradictory results in previous research and researchers' emphasis on the need for similar research in countries and different industries in domestic branding to generalise the results, the present study is done. Iran has a different political, cultural, economic and social structure compared to other countries, which is expected to achieve different results, and this important note is one of the main motivations for this research.

Research related to the attitudinal implications of internal branding, including brand loyalty, has also emphasised similar research in different geographical areas. The structure of Iran's insurance industry has significant differences with this industry in other countries, and the existence of significant differences in the study context of this study with other similar studies can draw researchers' attention to other possible factors influencing the consequences of internal branding. Therefore, this research is innovative in terms of examining the consequences of internal branding in a different context. Also, the role of psychological empowerment as a feature of employees in the consequences of internal branding has been ignored in previous research, which has been addressed in this study. 
Thus, this study aimed to investigate the effect of internal branding on financial performance and brand loyalty by considering the mediating role of psychological empowerment in Pasargad insurance in Iran.
The effect of internal branding

\section{The study context}

As one of the most important sectors providing long-term financial resources and due to its risk-distributing role, the insurance sector plays a significant role in the development of the business environment of each country (Tajpour et al., 2020; Hameed et al., 2021; Pereira et al., 2021). The performance of insurance companies contributes to improving the market value of individual firms and affects industrial growth, and ultimately affects the overall growth and prosperity of the countries' economy (Sharma et al., 2018). Assessing the determinants of insurers' performance in the corporate finance literature is essential. These companies, as financial intermediaries, provide the mechanism of risk transfer and channelise the funds appropriately to support business activities in the economy (Mehari and Aemiro, 2013). Therefore, analysing the financial and non-financial situation of insurance companies is important because of their role in improving the country's economic situation.

\section{Literature review}

\subsection{Internal branding}

Recent years have seen increased attention being given to internal branding (Zhang and $\mathrm{Xu}$, 2021). Internal branding is important to operationalise a brand orientation and enables an employee to deliver the expressed brand promise indispensable to implementing brandbuilding activities (Kaur et al., 2020). Internal branding theory stress that organisations should put their internal employees first because external customer loyalty happens only if service organisation employees adopt external customer relationship building orientation (Eid et al., 2019). Previous studies have identified internal brand communication, training, and leadership as the most critical internal brand activities (Zhang and $\mathrm{Xu}, 2021$ ). In the present study, these three activities are considered internal branding activities. A review of the literature suggests that the effect of internal branding on employee-related outcomes, including employee engagement (Ahmad et al., 2014, Park et al., 2014; Salamzadeh et al., 2016), employee intention to stay (Matanda and Ndubisi, 2013), quality commitment, identification, commitment and loyalty (Punjaisri et al., 2009; Punjaisri and Wilson, 2017), role clarity, affective and continuous commitment (Garas et al., 2018); brand performance (Tuominen et al., 2016), perceived person-organisation fit (Matanda and Ndubisi, 2013) and related results with the customer embracing customer-based brand equity (Hasni et al., 2018), positive customer image of company and purchase intention and brand experience (Ahmad et al., 2014) have been investigated. In this study, brand loyalty and financial performance are considered as the consequences of internal branding.

\subsection{Psychological empowerment}

Psychological empowerment refers to the internal motivation of employees to perform tasks. Employees experience psychological empowerment when they realise the importance of their job duties, which require skills and competencies. Also, they realise their autonomy to decide how they do their work and believe in their work to make a difference in achieving the organisation's goals (Singh and Singh, 2019). Psychological empowerment is a process in which the sense of self-efficacy of members of the organisation is boosted by identifying and removing unproductive conditions. This process can be implemented in formal business practices and informal techniques of presenting helpful information (Mostafa, 2017). Psychological empowerment includes four dimensions of meaning (value of work for person), 
competency (ability to do work), self-determination (independence) and impact (ability to influence outcomes) (Shah et al., 2019). Psychological empowerment has been recognised as an effective way of maintaining employees at work and a source of competitive advantage in organisations (Pigeon et al., 2017). Feelings of independence and competence, relevance, and employee self-efficacy can turn into favourable organisational behaviours (Shah et al., 2019).

\subsection{Brand loyalty}

Loyalty acts as a biased behaviour expressed over time by an individual with respect to one or more alternatives and is a function of psychological processes (Kim et al., 2016). Brand loyalty and employee loyalty are conceptualised by both attitudinal and behavioural elements. Employee's attitudes and behaviour have a crucial role in the service brand image formation process (Kimpakorn and Tocquer, 2010). In the service sector, in particular, employees deliver the brand experience to customers through their services, which must effectively create the brand spirit and values in customers' minds and allow customers to develop an emotional connection to the brand. Therefore, employees in service firms should understand what the brand stands for, i.e. its identity, but, more importantly, employees must be committed to supporting their brand and consistently delivering its promises to customers (Kimpakorn and Tocquer, 2010).

\subsection{Organisational financial performance}

Organisational performance reflects the extent of goal achievement in the organisation's workforce, capital, marketing and fiscal matters (Yesil and Kaya, 2013). Financial performance plays an ever-increasing role in organisations. Organisations can develop a more innovative and sustainable performance with pay attention to financial dimensions. Therefore, in this study, the organisation's financial performance is considered an important consequence of internal branding and psychological empowerment.

\section{Theoretical framework and hypotheses development}

\subsection{Internal branding and organisational performance}

Internal branding helps employees develop consistent brand behaviours to incorporate a sense of brand commitment into all of their daily work activities. Organisations, through internal branding, can foster a positive external perspective for themselves and thus gain the satisfaction of external customers (Ozçelik, 2015). Organisational communication and training can influence employees' supportive attitudes and behaviours towards the brand (Punjaisri et al., 2009). Behavioural branding determines the brand's contribution to organisational success. The results of Chernatony and Cottam (2006) research have emphasised that within the more successful financial services brands, staff with direct influence or involvement with branding matters were highly brand literate, having a comprehensive understanding of their brand and its implications for their job. Therefore, it can be inferred that more successful financial services brands have paid more attention to internal branding and raising employee knowledge of the brand. In addition, the results of research (Wang et al., 2019) showed that internal branding in the hotel is effective in talent retention, cost reduction and star rating. Therefore, internal branding can improve the organisation's performance, including its financial performance. Dunes and Pras (2017) has confirmed the positive and significant effect of brand management system on brand mental performance.

Lee et al. (2008) have reported that using well-rounded brand management systems in an organisation can boost brand performance, including financial performance. Similarly, previous research has confirmed the positive effect of brand management systems, including internal branding on organisational performance (Santos-Vijande et al., 2013). 
Internal branding by training employees helps them to support brand identity properly. In addition, as a result of establishing unbroken mutual communication between managers and employees, developing and reinforcing of brand is done well. This way, internal branding activities can improve customer service and thus positively affect the organisation's performance by aligning employee performance with brand commitments. This way, the following hypothesis can be proposed:

H1. Internal branding has a positive effect on the financial performance

\subsection{Internal branding and brand loyalty}

Internal branding, with a particular focus on employees, assures them that their organisation is a good workplace to engage to achieve organisational goals (Dechawatanapaisal, 2018). Thus, by building a passion for employees and institutionalising organisational values in their hearts, they engage in varied support for the organisation's brand. Internal branding programs can facilitate brand support behaviours by aligning employee behaviour with brand commitments communicated to customers (Sujchaphong et al., 2015). Profoundly effective inner branding administration can make a solid brand community inside the organisation. When a solid brand community exists inside an organisation, workers are more likely to comply with the set of exercises used by the organisation for brand guarantee conveyance through inner branding administration. As a result, representative brand devotion is fortified. Internal branding is positively associated with perceived employeeorganisation fit by employees and their intention to stay in the organisation (Matanda and Ndubisi, 2013). Previous studies have underlined the favourable effect of internal branding on employees' brand loyalty (Punjaisri and Wilson, 2011; Punjaisri et al., 2009; Punjaisri and Wilson, 2017) and organisational loyalty (Hasni et al., 2018). Employees in organisations that implement employee-centric or "internal service" cultures feel more respect and appreciation in their work environment (King and Grace, 2008), and this way will be more loyal to the brand. Given that, the following hypothesis can be proposed:

H2. Internal branding has a positive effect on brand loyalty.

\subsection{Internal branding and psychological empowerment}

According to the theory of psychological empowerment, it is necessary to foster an active motivational orientation among employees to empower their performance (Pigeon et al., 2017). Stronger relationships between employee and supervisor can lead to employees' psychological empowerment (Aryee and Chen, 2006), obtained in internal branding. Because through internal branding, employees' awareness, insights and abilities align with company goals and employees are empowered to fulfil brand commitments to customers (Hasni et al., 2018), it could be inferred that internal branding can boost the value of employees' tasks in their minds and have a favourable impact on their ability to do the job. When employees' perceptions of brand values embedded in brand commitments improve, they affect their clarity positively (Garas et al., 2018) and allow them to act in keeping with customer expectations (Punjaisri et al., 2009). This will enhance the competence of employees to fulfil their duties. Creating a brand-centric culture by delivering good quality internal customer service can establish brand supportive behaviour and ensure that employee behaviour is as consistent as possible with brand identity and values. Internal branding by establishing guiding principles for satisfactory brand behaviours motivates employees to apply these principles in their routine operations and thus affect organisational performance (Matanda and Ndubisi, 2013). The following hypothesis can therefore be proposed:

H3. Internal branding has a positive effect on psychological empowerment. 


\subsection{Psychological empowerment and financial performance}

Organisations can actualise powerful psychological resources by fulfilling the psychological needs of their employees through social and environmental factors. One of these resources is psychological empowerment (Mostafa, 2017). Feelings of empowerment act as a stimulus that guides employees' behaviour and elevates their performance. Empowered employees show greater commitment to their tasks by demonstrating consistency, thus feeling internal satisfaction. Powerful employees trust their ability to perform tasks, consider their work activities meaningful, feel the positive energy in their work, and are likely to perform better in their tasks (Avery et al., 2013) that can ultimately lead to improved organisational performance. The results of research by Hill and Bartol (2016) have shown that empowered leadership indirectly affects a team's performance (Hill and Bartol, 2016). In addition, the results of Iqbal et al. (2020) research confirm that psychological empowerment can enhance the direct effect of psychological safety and the indirect effect of sustainable leadership on sustainable performance. Psychological empowerment increases job efforts and job satisfaction (Laschinger et al., 2001) and has a positive effect on organisational performance (Patterson et al., 2004) and job productivity (Chang and Liu, 2008). Accordingly, the following hypothesis is presented:

H4. Psychological empowerment has a positive effect on the financial performance

\subsection{Psychological empowerment and brand loyalty}

Previous studies have indicated that psychological empowerment is positively associated with task performance, organisational citizenship behaviour and workspace advance (Seibert et al., 2011). Moreover, structural empowerment can reduce employees' willingness to serve (Smith et al., 2012). Kirrane et al. (2019) have emphasised the relationship between psychological empowerment and a high level of employees' commitment. Psychological empowerment could be a potential fundamental component. In other words, representatives who work in engaging working environments (i.e. having to get to data, openings, bolster and assets) are more likely to fortify their mental state of strengthening; in this manner, they may respond with elevated levels of engagement.

In the study conducted by Lee (2008), the positive effect of confidence in high performance on employee loyalty and the study conducted by Jose and Mampilly (2014), the positive relationship between psychological empowerment and employee engagement was confirmed. Previous studies have confirmed the impact of psychological empowerment on employee performance (Chiang and Hsieh, 2012; Li et al., 2015). Psychological empowerment empowers employees toward work, internalises task goals, and boosts higher endurance in challenging conditions in employees and leads to service-oriented behaviours (García-Juan et al., 2019). A positive relationship between empowerment and service performance (Aryee et al., 2012) as well as job performance (Avery et al., 2013; Liden et al., 2000; Maynard et al., 2014; Hill and Bartol, 2016) and job satisfaction (Lee and Nie, 2014; Chang et al., 2010) have been confirmed in previous research.

Along these lines, the following hypotheses can be formulated:

H5. Psychological empowerment has a positive effect on brand loyalty.

\subsection{The mediating role of psychological empowerment}

In the previous research, the mediating role of organisational loyalty (Hasni et al., 2018), perceived person-organisation fit (Matanda and Ndubisi, 2013), employee engagement (Park et al., 2014), affective commitment, and clarity of the role (Garas et al., 2018) and brand identification (Dechawatanapaisal, 2019) on the impact of internal branding on its consequences has been checked. 
A part of the extant research on leadership consequences emphasises the mediating role of psychological empowerment. According to the results of Joo and Jo (2017), psychological empowerment partially mediated the relationship between authentic leadership and organizational citizenship behaviour. Also, the relationship between core self-evaluations and organizational citizenship behaviour is mediated. In addition, the results of Chiu et al. (2020), the mediating effects of two dimensions of psychological empowerment (i.e. meaning and self-determination) in the relationship between Leader-member exchange and turnover intention is approved. Moreover, Barroso Castro et al. (2008) indicated that psychological empowerment mediates the relationship between transformational leadership and followers' attitudes. The mediating effects of psychological empowerment in the relationship between leadership styles and task performance have been confirmed by Ambad et al. (2021). Ali et al. (2021) also showed that humble leadership indirectly raised project success through psychological empowerment. In another study, Mansoor and Ali (2020) confirmed that psychological empowerment mediates the relationship between transformational leadership and both employee outcomes of organizational citizenship behaviour and turnover intention. Finally, Ahmad and Gao (2018) revealed that psychological empowerment partially mediates the relationship between ethical leadership and employee work engagement.

However, the mediating role of psychological empowerment in this regard has not been investigated in previous research. Past studies have confirmed the positive impact of psychological empowerment on organisational commitment (Chang et al., 2010; Lee and Nie, 2014; Hill and Bartol, 2016) and professional commitment (Lee and Nie, 2014).

The introduction of inside branding includes communication with and instructing representatives of almost the brand values to upgrade their mental and passionate engagement with the brand. Viable and steady communication and preparing that reflects brand messages can fulfil the taking after. To begin with, it empowers representatives to pick up brand information and to get it brand bits of knowledge. Moment lifts the mental contract between the organisation and the personal representative. Third, it drives worker internalisation of brand values. Whereas brand information empowers representatives to get the brand and wanted work behaviours, the fulfilment of the mental contract rouses workers to internalise and live the brand (Dechawatanapaisal, 2018).

Accordingly, it could be deduced that psychological empowerment can elevate internal branding efforts and lead to greater employee loyalty and optimal organisational performance.

H6. Psychological empowerment mediates the effect of internal branding on financial performance

H7. Psychological empowerment mediates the effect of internal branding on brand loyalty

The conceptual model of research is presented in Figure 1.

\section{Research design and methodology}

\subsection{Sample and data collection}

Statistical power analysis was employed to estimate sample size, using SPSS Sample Power software, based on two independent variables, $95 \%$ confidence level (probability of first type error 0.05 ), Power for increment $80 \%$ and a detectable effect size of 0.05 , an optimal sample size of at least 187 was considered. To increase the response rate, 230 questionnaires were distributed among Pasargad's insurance staff electronically and in person. Of the 220 returned questionnaires, 200 were eligible for analysis and entered the analysis stage. Data were collected from the employees of different branches of Pasargad Insurance in Iran. Some data were collected by sending an online questionnaire through the internal intranet of 


\section{JABES}

Figure1.

Proposed model

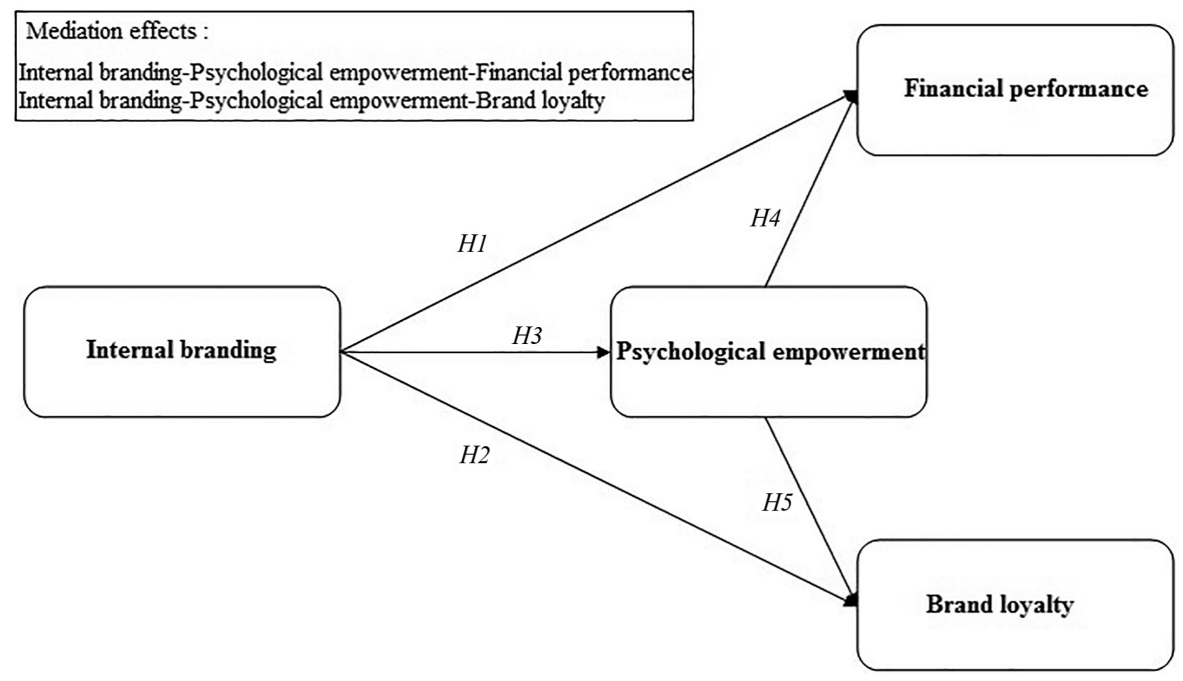

Pasargad Insurance Company, and the other part of the data was collected in person. Descriptive analysis of the data shows that $71.5 \%$ of the respondents were male, and $66.5 \%$ of them were between $30-40$ years old. $57.5 \%$ had a bachelor's degree, and 70\% had 6-15 years of work experience.

\subsection{Measures}

Questions related to the research structures were extracted from the relevant literature. Internal branding was designed based on research by Garas et al. (2018). The financial performance of Pasargad's insurance company was measured by four Concepts (ROI, ROE, Sales growth, ROA) based on available data from March 2010 to March 2020. ROI is calculated through deducting the initial value of the investment from the final value (which equals the net return), then dividing this new number (the net return) by the cost of the investment, and, finally, multiplying it by 100 . ROE is calculated based on net income divided by shareholders' equity. Sales growth is calculated based on Log (sales), and ROA is calculated based on business's net income divided by total assets. Psychological empowerment was measured with seven items from the research Kundu et al. (2019). Brand loyalty was also measured by two items and based on research Punjasri and Wilson (2011). A five-point Likert scale was used to complete the questionnaire. The researchers make this questionnaire comprehensible for the respondents (see Table 1).

\section{Analysis and results}

The conceptual model of the research was analysed using structural equation modelling (SEM) by the partial least squares approach (Ringle et al., 2015) and PLSPM (Sanchez, 2013), and MATRIXPLS (Rosseel, 2012) packages in $R$ software. In exploratory research and theory development, it is more appropriate to use variance-based structural equation modelling than confirmatory research. Due to the research innovation in the use of psychological empowerment as a mediator variable, the variance-based approach was used to analyse the conceptual model in this research. The conceptual model analysis is performed in two stages to evaluate the validity and reliability of the measurement models as well as the structural model analysis. The explanations for these two stages are presented next. 


\begin{tabular}{|c|c|c|c|c|}
\hline Constructs & Items and sources & Mean & $\mathrm{SD}$ & \\
\hline \multicolumn{4}{|c|}{ Internal branding (Garas et al., 2018) } & bra \\
\hline IB1 & The company I work for communicates its brand promise well to its employees & 3.81 & 1.02 & \\
\hline IB2 & $\begin{array}{l}\text { The company I work for communicates the importance of my role in delivering } \\
\text { the brand promise }\end{array}$ & 3.61 & 1.15 & \\
\hline IB3 & $\begin{array}{l}\text { Internal communications provide all the essential information for me to perform } \\
\text { the service according to the brand's expectations }\end{array}$ & 3.73 & 1.13 & \\
\hline IB4 & $\begin{array}{l}\text { The brand's mission and its promise are constantly reinforced through internal } \\
\text { communications }\end{array}$ & 3.43 & 1.20 & \\
\hline IB5 & $\begin{array}{l}\text { My manager regularly meets all employees to report issues relating to the whole } \\
\text { company }\end{array}$ & 3.30 & 1.31 & \\
\hline IB6 & New employees are oriented towards the company's vision, mission and values & 3.30 & 1.21 & \\
\hline IB7 & The company teaches me why things should be done, not just how to do them & 3.39 & 1.21 & \\
\hline IB8 & $\begin{array}{l}\text { The company provides me with appropriate skills in relation to delivering the } \\
\text { brand's promise based on the brand's standards }\end{array}$ & 3.31 & 1.20 & \\
\hline IB9 & $\begin{array}{l}\text { This company has the flexibility to accommodate the different training needs of } \\
\text { employees }\end{array}$ & 3.64 & 1.06 & \\
\hline IB10 & $\begin{array}{l}\text { Training programs help me better understand current and future customers' } \\
\text { needs }\end{array}$ & 3.17 & 1.18 & \\
\hline IB11 & I receive enough information from my boss about my job performance & 3.20 & 1.11 & \\
\hline IB12 & I periodically receive feedback from my boss on my job performance & 3.31 & 1.06 & \\
\hline $\mathrm{IB} 13$ & I am informed about how the bank rewards employees & 3.43 & 1.18 & \\
\hline IB14 & The reward system in this bank is linked to business goals & 3.32 & 1.10 & \\
\hline IB15 & My company compensates employees for providing brand- related information & 4.14 & 0.88 & \\
\hline \multirow{2}{*}{\multicolumn{5}{|c|}{$\begin{array}{l}\text { Financial performance } \\
\text { Financial performance of Pasargad's insurance company was measured by four Concepts(ROI, } \\
\text { ROE, Sales growth, ROA) based on available data from March } 2010 \text { to March } 2020\end{array}$}} \\
\hline & & & & \\
\hline FP1 & Return on Investment (ROI) & 0.06 & 0.04 & \\
\hline FP2 & Return on equity (ROE) & 0.25 & 0.14 & \\
\hline FP3 & Sales' growth & 0.18 & 0.19 & \\
\hline FP4 & Return on Assets (ROA) & 0.06 & 0.03 & \\
\hline \multicolumn{5}{|c|}{ Brand loyalty (Punjasri and Wilson, 2011) } \\
\hline BL1 & I Will be happy to spend the rest of my career in this insurance company & 4.08 & 1.17 & \\
\hline BL2 & $\begin{array}{l}\text { My intention to stay is driven by the fact that I am competent in delivering the } \\
\text { brand promise }\end{array}$ & 4.05 & 1.05 & \\
\hline \multicolumn{5}{|c|}{ Psychological empowerment (Kundu et al., 2019) } \\
\hline PC1 & The work I do is very important to me & 4.00 & 0.98 & \multirow{7}{*}{$\begin{array}{r}\text { Table 1. } \\
\text { Composition of the } \\
\text { scales and descriptive } \\
\text { statistics }\end{array}$} \\
\hline PC2 & My job activities are personally meaningful to me & 4.21 & 0.96 & \\
\hline PC3 & I am confident about my ability to do my job & 4.42 & 0.79 & \\
\hline $\mathrm{PC} 4$ & I have mastered the skills necessary for my job & 3.43 & 1.16 & \\
\hline PC5 & I have significant autonomy in determining how I do my job & 3.28 & 0.98 & \\
\hline PC6 & $\begin{array}{l}\text { I have considerable opportunity for independence and freedom in how I do my } \\
\text { job }\end{array}$ & 3.62 & 1.11 & \\
\hline PC7 & I have a large impact on what happens in my section of this department & 3.91 & 0.98 & \\
\hline
\end{tabular}

\subsection{Measurement model}

The validity and reliability of the research structures were evaluated. The convergent validity of the model was examined with outer loadings. Some researchers consider the value of over 0.4 for outer loadings to be a convergence validity (Hair et al., 2019; Kelidbari et al., 2016; Roshandel-Arbatani et al., 2019). Outer loadings of all research items are above 0.4, and therefore their validity is confirmed. Convergent validity for the research constructs was assessed using AVE criteria. Since the AVE values for three structures were above 0.5 
(Hair et al., 2019; Ebrahimi et al., 2021a, b; Fekete-Farkas et al., 2021), their validity is confirmed (Table 2). However, values above 0.4 are acceptable if discriminant validity is not compromised (Ebrahimi and Mirbargkar, 2017). Hence convergent validity of psychological empowerment is confirmed too. With respect to values less than 1 in the HTMT matrix (Soleimani et al., 2021), based on Table 3, discriminant validity was confirmed for construct level. Meanwhile, discriminant validity in items level was tested with cross-loading (Hair et al., 2019). To test discriminant validity in the level of indicators, cross-loadings have been used, by plspm package of $R$ (Sanchez, 2013). Figure 2 implies discriminant validity in the level of indicators. The reliability of questionnaire evaluated and confirmed by Cronbach's alpha, Dillon-Goldstein's rho and Composite reliability (CR). Some researchers suggest 0.7 and above as the favourable point for these indices (Rosseel, 2012; Moghadamzadeh et al., 2020; Janavi et al., 2021).

\begin{tabular}{|c|c|c|c|c|c|c|c|}
\hline Constructs & Indicators & $\begin{array}{c}\text { Outer } \\
\text { loadings }\end{array}$ & AVE & $\begin{array}{c}\text { Cronbach's } \\
\alpha\end{array}$ & DG.rho & $\mathrm{CR}$ & $\begin{array}{l}\text { Model } \\
\text { type }\end{array}$ \\
\hline Internal branding & $\begin{array}{l}\text { IB1 } \\
\text { IB2 } \\
\text { IB3 } \\
\text { IB4 } \\
\text { IB5 } \\
\text { IB6 } \\
\text { IB7 } \\
\text { IB8 } \\
\text { IB9 } \\
\text { IB10 } \\
\text { IB11 } \\
\text { IB12 } \\
\text { IB13 } \\
\text { IB14 } \\
\text { IB15 }\end{array}$ & $\begin{array}{l}0.66 \\
0.64 \\
0.57 \\
0.61 \\
0.77 \\
0.78 \\
0.81 \\
0.79 \\
0.78 \\
0.81 \\
0.78 \\
0.82 \\
0.76 \\
0.63 \\
0.50\end{array}$ & 0.52 & 0.93 & 0.94 & 0.94 & Reflective \\
\hline $\begin{array}{l}\text { Psychological } \\
\text { empowerment }\end{array}$ & $\begin{array}{l}\text { PE1 } \\
\text { PE2 } \\
\text { PE3 } \\
\text { PE4 } \\
\text { PE5 } \\
\text { PE6 } \\
\text { PE7 }\end{array}$ & $\begin{array}{l}0.70 \\
0.76 \\
0.72 \\
0.58 \\
0.66 \\
0.60 \\
0.48\end{array}$ & 0.42 & 0.77 & 0.84 & 0.84 & Reflective \\
\hline Brand loyalty & $\begin{array}{l}\text { BL1 } \\
\text { BL2 }\end{array}$ & $\begin{array}{l}0.85 \\
0.88\end{array}$ & 0.74 & 0.75 & 0.85 & 0.85 & Reflective \\
\hline Financial performance & $\begin{array}{l}\text { FP1 } \\
\text { FP2 } \\
\text { FP3 } \\
\text { FP4 }\end{array}$ & $\begin{array}{l}0.93 \\
0.85 \\
0.76 \\
0.91\end{array}$ & 0.75 & 0.90 & 0.93 & 0.93 & Reflective \\
\hline
\end{tabular}

Table 2.

Outer loadings, AVE, Cronbach's alpha, DG.rho and CR of constructs

\begin{tabular}{lcccr}
\hline & $\mathrm{IB}$ & $\mathrm{PE}$ & $\mathrm{BL}$ & $\mathrm{FP}$ \\
\hline $\mathrm{IB}$ & & & \\
$\mathrm{PE}$ & 0.58 & 0.62 & \\
$\mathrm{BL}$ & 0.57 & 0.74 & 0.52 \\
$\mathrm{FP}$ & 0.38 & & \\
Note(s): $\mathrm{IB}=$ Internal Branding, & PE $=$ Psychological Empowerment, $\mathrm{BL}=$ Brand Loyalty \\
FP= Financial Performance & & \\
\end{tabular}


The effect of

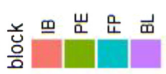
internal branding

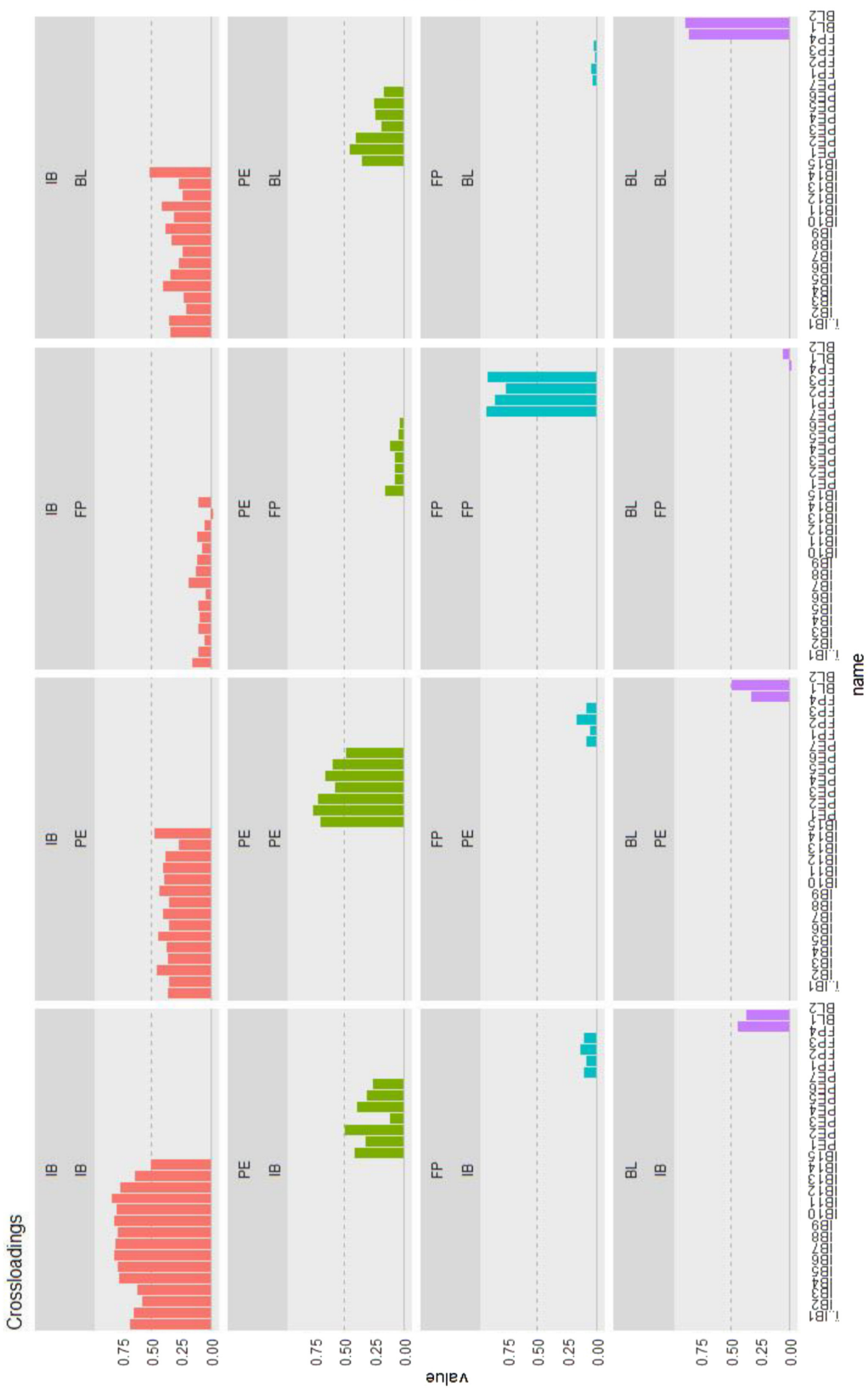

Figure 2. Cross-loadings for indicators 


\subsection{Structural model and hypothesis analysis}

The research hypotheses were analysed by examining the standard path coefficients in the structural model. Bootstrapping technique with 5,000 repeaters was used to test the hypotheses (Figure 3). Based on the values obtained for $R^{2}$, it can be said that $29.2 \%$ of the variance of psychological empowerment, $28.6 \%$ of the variance of brand loyalty and only $2 \%$ of the variance of financial performance are explained by the model. Hence, we can claim that the financial performance of Pasargad's insurance company is not affected by internal branding and psychological empowerment. On the other hand, brand loyalty is affected by internal branding and psychological empowerment. The predictive power of the model was analysed using the Stone-Geisser test (Ebrahimi et al., 2021c; Khajeheian and Ebrahimi, 2021). The results indicate that the value of $\mathrm{Q} 2$ is positive for the dependent variables, and therefore, the independent variables have the ability to predict the dependent variables. Based on the results, internal branding did not significantly affect financial performance $(\beta=0.09$, $p$-value $>0.05$ ), so the $\mathrm{H} 1$ hypothesis is not confirmed. $\mathrm{H} 2$ hypothesis is confirmed by examining the impact factor of internal branding on brand loyalty $(\beta=0.28, p$-value $<0.05)$. The results show that internal branding positively affects psychological empowerment $(\beta=0.54, p$ value $<0.05$ ); thus, the H3 hypothesis is confirmed. Based on the results, psychological empowerment did not significantly affect financial performance $(\beta=0.08$, $p$-value $>0.05)$. Furthermore, the effect of psychological empowerment on brand loyalty $\beta=0.33$, $p$ value $<0.05$ ) is confirmed (see Table 4 ).

\subsection{Mediating effect of psychological empowerment}

To investigate the mediating effect of psychological empowerment, the overall direct and indirect effects of internal branding on financial performance as well as brand loyalty were examined. Considering the not significant overall effect $(\beta=0.13$, $p$-value $>0.05)$ of internal branding on financial performance, can be deduced that psychological empowerment did not play a mediating role in the relationship of internal branding to financial performance.

Figure 3.

PLSPM output for SEM

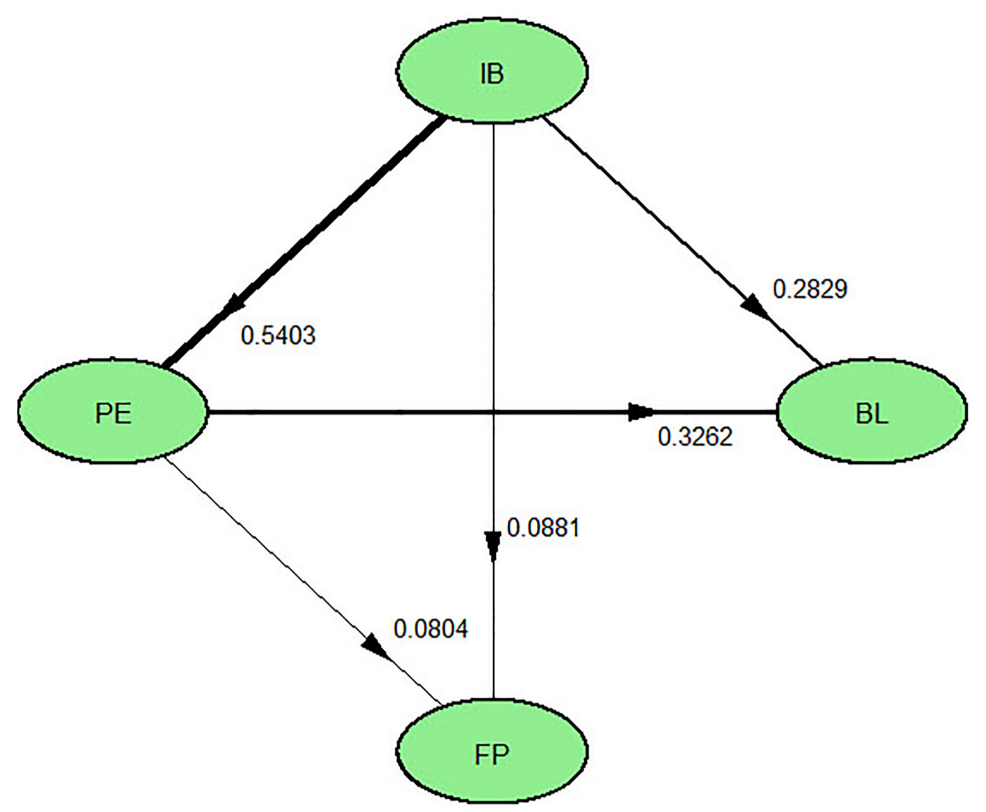


On the other hand, since the results confirm the significant overall effect $(\beta=0.46, p<0.05)$, significant direct $(\beta=0.28, p<0.05)$ and indirect effect $(\beta=0.18, p<0.05)$ of internal branding on brand loyalty, so it can be argued that psychological empowerment has a partial mediating role in the relationship of internal branding to brand loyalty (see Table 5).

\section{Discussion}

Due to researchers' emphasis on conducting research related to internal branding in geographical areas and various industries, this research is known as the first research conducted in the Iranian insurance industry in the field of internal branding implications. This study emphasises the importance of considering the specific conditions of each region and industry in interpreting the results related to the consequences of internal branding.

In particular, the present study examines whether human resource management efforts in the field of internal branding in Iran Pasargad Insurance can improve employee brand loyalty as well as the financial performance of Pasargad Insurance. In addition, this study answers the question of whether psychological empowerment can mediate the possible effects of internal branding on brand loyalty and financial performance. According to the results, internal branding and psychological empowerment do not affect financial performance. This means that the activities performed by employees in the organisation to deeply understand the meaning of the brand and strengthen the employees' sense of empowerment cannot significantly improve the financial performance of Pasargad Insurance Company.

The absence of the effect of internal branding on financial performance has been confirmed in research (Lee et al., 2008; Tuominen et al., 2016). It is noteworthy that the financial performance of Pasargad Insurance Company has been measured with objective data that should be taken into account. In addition, the lack of impact of domestic branding on financial performance can be accurately interpreted on the special and different conditions of the Iranian insurance industry compared to developed countries. Iran's insurance industry suffers from several structural problems, and by interviewing senior managers and experts of the company, we will address some of the most important issues mentioned by them. Among the most important problems of the Iranian insurance industry can be affected by government interference in the pricing of various insurance rates, the receipt of premium income taxes by the government, the dependence of many insurance companies, including

\begin{tabular}{llrrrrr}
\hline & & & & High & \\
Hypotheses & & $\beta$ & Low CI & CL & Supported & \\
\hline H1 & Internal branding $\rightarrow$ Financial performance & 0.09 & -0.12 & 0.24 & No \\
H2 & Internal branding $\rightarrow$ brand loyalty & 0.28 & 0.16 & 0.42 & Yes & \\
H3 & Internal branding $\rightarrow$ psychological empowerment & 0.54 & 0.44 & 0.64 & Yes & \\
H4 & Psychological empowerment $\rightarrow$ Financial & 0.08 & -0.13 & 0.26 & No & Table 4. \\
& performance & & & & & \\
H5 & Psychological empowerment $\rightarrow$ brand loyalty & 0.33 & 0.15 & 0.47 & Yes & \\
& & & & & & results \\
\hline
\end{tabular}

\begin{tabular}{llllll}
\hline & & & & Effect type \\
Independent variable & Dependent variable & Total & Direct & Indirect & Mediating effect \\
\hline Internal branding & financial performance & 0.13 & 0.09 & 0.04 & No \\
& Brand loyalty & $0.46^{* *}$ & $0.28^{* * *}$ & $0.18^{* *}$ & Partial
\end{tabular}

Note(s): $* * p \leq 0.05$
The effect of
internal
branding 
Pasargad Insurance, on some banks and Taking them away from the risks of the banking industry, including the US embargo on the industry, the major shareholding of insurance companies by individuals and mismanagement of shareholders in the field of investment, the lack of growth of insurance culture in the country, inadequate risk management in companies Insurance, more than $90 \%$ share of non-life insurance and insignificant share of life insurance in the composition of received insurance, limited number of insurance companies and inactivity of foreign companies in the country, resulting in reduced competitiveness and lack of attention to quality Insurance services and customer satisfaction, the small share of insurance companies' assets in long-term investments and, finally, the impact of maximum sanctions on the country's economic situation and the high vulnerability of all companies, including insurance companies operating in the country, noted.

In fact, the Insurance industry in Iran has significant challenges related to financial performance, and as a result, efforts to improve the performance of the workforce of companies cannot significantly improve the financial situation of these companies. Despite the significant changes in the last two decades, the Iranian insurance industry is still facing a low insurance penetration rate and inadequate development indicators compared to global and regional statistics, resulting from the weaknesses and challenges of Iran's insurance industry compared to developed ones one's countries. Thus, it can be analysed that the financial performance of insurance companies is affected by the fundamental structural problems of the insurance industry and severe economic problems in Iran, as a result, the possible efforts of these companies to strengthen internal branding and employee psychological empowerment is also ineffective. The effect of psychological empowerment on financial performance has not been considered in previous research, but the positive relationship between empowerment and service performance (Aryee et al., 2012) as well as job performance (Liden et al., 2000; Avery et al., 2013; Maynard et al., 2014) have been confirmed in previous research.

Another result showed that internal branding had a positive effect on brand loyalty. Therefore, investigating internal branding activities, including internal communication, orientation and training, and feedback, can make employees more loyal to the brand. An indepth understanding of brand values through internal branding activities can reinforce employees' sense of belonging to the organisation's brand and lead them to gain brand support. This result is consistent with the research of Punjaisri and Wilson (2011), Punjaisri et al. (2009) and Punjaisri and Wilson (2017). Nevertheless, in research (Dechawatanapaisal, 2019), the effect of internal branding on brand loyalty has not been directly confirmed, and it is only confirmed by the full mediation role of the brand identification variable. Dechawatanapaisal's (2019) study has emphasised the effect of internal branding on strengthening employees' sense of belonging to the organisation's brand, which affects their brand recognition and ultimately leads to employee loyalty. In other words, the results of this study and previous research show that the efforts of organisations to strengthen internal branding, can directly or indirectly strengthen employee loyalty.

According to the results, internal branding has a positive effect on employees' psychological empowerment. In fact, internal branding can improve employees' sense of self-efficacy at work by building a shared understanding of brand values in their minds. Employees can better understand their brand values through internal branding activities, have more control over their work, and feel more qualified to perform their job duties. According to Aryee and Chen (2006), the quality of communication between supervisors and staff can enhance the psychological empowerment of employees. In addition, the impact of internal marketing on psychological empowerment in Yao et al. (2013) research has been confirmed.

According to the results, psychological empowerment has a positive effect on brand loyalty. Therefore, it can be said that if employees feel confident and have a strong intrinsic motivation for their business activities, their sense of belonging to the brand will be 
strengthened. The positive impact of psychological empowerment on organisational commitment has been confirmed in past researches (Avolio et al., 2004; Liden et al., 2000).

\subsection{Managerial implications}

This study emphasises the importance of internal branding to enhance employees' psychological empowerment and loyalty to the organisation's brand. Strengthening internal communications, especially facilitating the mutual relationship between managers and employees, is crucial. Managers must continually improve the organisation's internal communications by providing daily briefings, group meetings, notice boards and corporate magazines. The other responsibility of managers to enhance internal branding is to pay attention to the skill needs associated with the brand of employees, which needs to be properly assessed and appropriate training courses are organised. Brand-related training courses can include general skills and special skills that the use of expert specialists can enhance employees' ability to perform brand-related tasks and improve their behavioural performance. Providing continuous performance feedback to employees can inform them of the quality of their performance and boost their motivation to perform their tasks better. Linking the reward systems to company goals and employee-related brand performance, including human resource management strategies, reinforces brand-related behaviour. Therefore, enhancing internal branding by improving internal communication, conducting training courses, providing continuous feedback to employees, and designing a reward system appropriate to brand-related behaviour can improve employees' understanding of the brand promise and make them emotionally empowered and lead to greater loyalty to the brand.

The study also suggests that employee loyalty to the brand will be enhanced by improving employees' psychological empowerment. Therefore, it is necessary for managers to examine the status of the dimensions of employee psychological empowerment and, considering existing weaknesses, to enhance employees' sense of meaningfulness, autonomy, influence, and competence. Managers can improve their employees 'positive attitude toward their ability to perform their duties by helping to improve employees' psychological empowerment and thereby help them improve their organisational performance. It also reinforces the feeling of empowerment in employees, enhancing their loyalty to the brand. Organisations can enhance employees' sense of empowerment through various human resource management strategies. For example, applying methods for confidence-building practice, clear task specification, goal clarification and design of meaningful jobs can improve employee psychological empowerment (Mostafa, 2017) and strengthen employee brand loyalty.

\subsection{Limitations and future research}

The present study has some limitations. One of the limitations is researching one of the insurance companies in Iran. The research model needs to be tested in other service organisations and commodities for a more detailed analysis. On the other hand, the generalisation of the results of this research is limited. The reason for this is the unique economic structure of Iran, which may not be comparable to any of the developing or developed countries. Traditional thinking in many pillars of insurance in Iran and the restrictions imposed due to economic and structural problems have created unique conditions for insurance companies. Therefore, caution should be exercised in generalising the results of this research. To better understand the issue, future researchers should evaluate the conceptual model of the present research in the insurance industry of other countries, developed and developing.

\section{Conclusion}

The present study is intended for managers of service organisations, especially insurance organisations, with practical implications. According to the results, managers of insurance
The effect of internal branding

$-$


companies in Iran cannot improve the financial performance of their collection through the use of human resource management strategies. Surveys show that Insurance companies, like banks, face the problem of unproductive assets; in such a way that receivables occupy a major part of their assets. A look at the financial situation of private insurance companies in Iran, including Pasargad Insurance Company in 2018, shows that the growth of profitability of many of these companies is not due to improving their insurance operations, but mainly from profits from currency exchange. In fact, Pasargad Insurance is the third largest private insurance company in Iran in terms of assets; but more noteworthy in this regard is that unlike other companies in the group, about $60 \%$ of the company's assets are allocated to investments ( $50 \%$ short-term and 10\% long-term), the main part of which is related to shortterm and long-term bank deposits. However, studies show the results of company insurance performance in the field of insurance in 2019-2020 has been loss-making. However, due to the significant return on investment, this loss was fully offset. This has been an important alarm for the company's financial performance, which should be addressed by adopting appropriate fiscal policies in line with Iran's inflationary economy.

In fact, it should be noted that the insurance industry in Iran is facing high risk. The focus of managers of insurance companies in Iran is not only on internal processes and branding. Problems of sanctions and problems in some insurance policies have posed many challenges to managers of insurance companies. One of the important components in understanding the insurance industry is the loss ratio. In Iran, the loss ratio should be below $80 \%$ so that companies can operate more easily, indicating the high risk factor of insurance companies in Iran.

Iran's insurance industry is far from the insurance industry in developed countries. The insurance diffusion coefficient of $2.3 \%$ in Iran reflects this fact, while in the countries of the region, the diffusion coefficient is over $10 \%$, and we are far from them. The main problem is the low diffusion coefficient, according to many experts, is people distrust in this industry. It seems that one of the issues that the Iranian insurance industry and insurance managers have been unaware of it is the non-entry of the insurance industry into the financial markets and the issuance of securities because the insurance risk can be distributed to the rest of the economic sectors of the country, and a solution can be found for sanctions by doing it.

In line with interviews with some managers in the insurance industry, it can be stated that the first challenge of the insurance industry is the implementation of IFRS financial reporting standards in insurance companies. Also, insurance managers and policymakers in Iran should pay special attention to managing the risks in the insurance industry, correct and accurate pricing of premiums, preventing non-compliance of assets and liabilities.

It seems that another important factor in improving the financial performance of Pasargad Insurance and insurance companies is the specialisation of companies in providing insurance services given the separation of life and non-life insurances. Centralisation and specialisation of different sectors in providing insurance services are missing links in the Iranian insurance industry. Iran's insurance industry faces many challenges such as lack of capital, lack of specialised personnel, a significant volume of overdue receivables and lack of professional programs to supply the products needed by the people. Proper interaction between government and insurance companies by consulting with insurance companies' experts is also a significant gap in the Iranian insurance industry. Insurance companies expect the government to be involved in insurance policies to improve their financial performance and to examine their real problems expertly.

It is noteworthy that apart from some incorrect policies that affect the financial performance of insurance companies, some internal problems in insurance companies should be considered by senior managers. Clarifying the financial statements of insurance companies, identifying potential fictitious profits accumulated from the past, and compensating the deficit of insurance reserves from this source are other important measures that distort the image of internal branding. 
Also, the weakness of technology in insurance companies has always been mentioned by some critics. Iran's insurance industry is in the early stages of using information technology and appropriate software in the production and collection, and registration of data for analysis, policymaking, and decision making. Recent advances in new technologies, including mobile phones, have provided an opportunity for insurance companies to integrate technology into their businesses to offer new products and services and revitalise their old and unattractive technical and financial fields and investments. The managers of insurance companies should consider this important point to improve financial performance.

\section{References}

Ahmad, I. and Gao, Y. (2018), "Ethical leadership and work engagement: the roles of psychological empowerment and power distance orientation”, Management Decision, Vol. 56 No. 9, pp. 1991-2005.

Ahmad, N., Iqbal, N., Kanwal, R., Javed, H. and Javed, K. (2014), "The mediating role of employee engagement in relationship of internal branding and brand experience: case of service organisations of Dera Ghazi Khan", Business and Management, Vol. 6 No. 4, pp. 26-41.

Ali, M., Li, Z., Haider, M., Khan, S. and Din, Q.M.U. (2021), "Does humility of project manager affect project success? Confirmation of moderated mediation mechanism", Management Research Review, Vol. 44 No. 9, pp. 1320-1341.

Ambad, S.N.A., Kalimin, K.M., Damit, D.H.D.A. and Andrew, J.V. (2021), "The mediating effect of psychological empowerment on leadership styles and task performance of academic staff", Leadership and Organization Development Journal, Vol. 42 No. 5, pp. 763-782.

Aryee, S. and Chen, Z.X. (2006), "Leader-member exchange in a Chinese context: antecedents, the mediating role of psychological empowerment and outcomes", Journal of Business Research, Vol. 59 No. 7, pp. 793-801.

Aryee, S., Walumbwa, F.O., Seidu, E.Y. and Otaye, L.E. (2012), "Impact of high-performance work systems on individual-and branch-level performance: test of a multilevel model of intermediate linkages", Journal of Applied Psychology, Vol. 97 No. 2, p. 287.

Avery, D.R., Wang, M., Volpone, S.D. and Zhou, L. (2013), "Different strokes for different folks: the impact of sex dissimilarity in the empowerment-performance relationship", Personnel Psychology, Vol. 66 No. 3, pp. 757-784.

Avolio, B.J., Zhu, W., Koh, W. and Bhatia, P. (2004), “Transformational leadership and organisational commitment: mediating role of psychological empowerment and moderating role of structural distance", Journal of Organizational Behavior: The International Journal of Industrial, Occupational and Organisational Psychology and Behavior, Vol. 25 No. 8, pp. 951-968.

Barroso Castro, C., Villegas Perinan, M.M. and Casillas Bueno, J.C. (2008), "Transformational leadership and followers' attitudes: the mediating role of psychological empowerment”, The International Journal of Human Resource Management, Vol. 19 No. 10, pp. 1842-1863.

Chang, L.C. and Liu, C.H. (2008), "Employee empowerment, innovative behavior and job productivity of public health nurses: a cross-sectional questionnaire survey", International Journal of Nursing Studies, Vol. 45 No. 10, pp. 1442-1448.

Chang, L.C., Shih, C.H. and Lin, S.M. (2010), "The mediating role of psychological empowerment on job satisfaction and organisational commitment for school health nurses: a cross-sectional questionnaire survey", International Journal of Nursing Studies, Vol. 47 No. 4, pp. 427-433.

Chiang, C.F. and Hsieh, T.S. (2012), "The impacts of perceived organisational support and psychological empowerment on job performance: the mediating effects of organisational citizenship behavior", International Journal of Hospitality Management, Vol. 31 No. 1, pp. 180-190.

Chiu, W., Hui, R.T.Y., Won, D. and Bae, J.S. (2020), "Leader-member exchange and turnover intention among collegiate student-athletes: the mediating role of psychological empowerment and the moderating role of psychological contract breach in competitive team sport environments", European Sport Management Quarterly, pp. 1-27, doi: 10.1080/16184742.2020.1820548.
The effect of internal branding 
De Chernatony, L. and Cottam, S. (2006), "Internal brand factors driving successful financial services brands", European Journal of Marketing, Vol. 40 Nos 5/6, pp. 611-633, doi: 10.1108/ 03090560610657868.

Dechawatanapaisal, D. (2018), "Employee retention: the effects of internal branding and brand attitudes in sales organisations", Personnel Review, Vol. 47 No. 3, pp. 675-693.

Dechawatanapaisal, D. (2019), "Internal branding and employees' brand outcomes: do generational differences and organisational tenure matter?", Industrial and Commercial Training, Vol. 51 No. 4, pp. 209-227, doi: 10.1108/ICT-10-2018-0089.

Dunes, M. and Pras, B. (2017), "The impact of the brand management system on performance across service and product-oriented activities", Journal of Product and Brand Management, Vol. 26 No. 3, pp. 294-311, doi: 10.1108/JPBM-09-2015-0995.

Ebrahimi, P. and Mirbargkar, S.M. (2017), "Green entrepreneurship and green innovation for SME development in market turbulence”, Eurasian Business Review, Vol. 7 No. 2, pp. 203-228.

Ebrahimi, P., Hamza, K.A., Gorgenyi-Hegyes, E., Zarea, H. and Fekete-Farkas, M. (2021a), "Consumer knowledge sharing behavior and consumer purchase behavior: evidence from E-commerce and online retail in Hungary”, Sustainability, Vol. 13 No. 18, 10375, doi: 10.3390/su131810375.

Ebrahimi, P., Salamzadeh, A., Gholampour, A. and Fekete-Farkas, M. (2021b), "Social networks marketing and Hungarian online consumer purchase behavior: the microeconomics strategic view based on IPMA matrix", Academy of Strategic Management Journal, Vol. 20 No. 4, pp. 1-7.

Ebrahimi, P., Soleimani, M., Kot, S., Fekete-Farkas, M. and Alipour, H. (2021c), "COVID-19 crisis and online businesses resilience: a moderated mediation model", European Journal of International Management. doi: 10.1504/EJIM.2021.10038240 (forthcoming).

Eid, R., Al Zaabi, A., Alzahmi, R. and Elsantil, Y. (2019), "Integrating internal branding antecedents, customer and job satisfaction in the public sector", International Journal of Organizational Analysis, Vol. 27 No. 5, pp. 1480-1503.

Fekete-Farkas, M., Gholampour, A., Bouzari, P., Jarghooiyan, H. and Ebrahimi, P. (2021), "How gender and age can affect consumer purchase behavior? Evidence from A microeconomic perspective from Hungary", AD Minister, Vol. 39, pp. 25-46.

Garas, S.R.R., Mahran, A.F.A. and Mohamed, H.M.H. (2018), "Internal corporate branding impact on employees' brand supporting behaviour", Journal of Product and Brand Management, Vol. 27 No. 1, pp. 79-95.

García-Juan, B., Escrig-Tena, A.B. and Roca-Puig, V. (2019), "The empowerment-organisational performance link in local governments", Personnel Review, Vol. 48 No. 1, pp. 118-140.

Hair, J.F., Risher, J.J., Sarstedt, M. and Ringle, C.M. (2019), "When to use and how to report the results of PLS-SEM", European Business Review, Vol. 31 No. 1, pp. 2-24, doi: 10.1108/EBR-11-2018-0203.

Hameed, N.S.S., Salamzadeh, Y., Rahim, N.F.A. and Salamzadeh, A. (2021), "The impact of business process reengineering on organizational performance during the coronavirus pandemic: moderating role of strategic thinking”, foresight. doi: 10.1108/FS-02-2021-0036.

Hasni, M.J.S., Salo, J., Naeem, H. and Abbasi, K.S. (2018), "Impact of internal branding on customerbased brand equity with mediating effect of organisational loyalty: an empirical evidence from retail sector", International Journal of Retail and Distribution Management, Vol. 46 Nos 11-12, pp. 1056-1076.

Hill, N.S. and Bartol, K.M. (2016), "Empowering leadership and effective collaboration in geographically dispersed teams”, Personnel Psychology, Vol. 69 No. 1, pp. 159-198.

Iqbal, Q., Ahmad, N.H. and Nasim, A. (2020), "A moderated-mediation analysis of psychological empowerment: sustainable leadership and sustainable performance", Journal of Cleaner Production, Vol. 262, p. 121429, doi: 10.1016/j.jclepro.2020.121429.

Janavi, E., Soleimani, M., Gholampour, A., Friedrichsen, M. and Ebrahimi, P. (2021), "Effect of social media adoption and media needs on online purchase behavior: the moderator roles of media type, gender and age", Journal of Information Technology, Vol. 13 No. 2, pp. 1-24. 
Joo, B.K. and Jo, S.J. (2017), "The effects of perceived authentic leadership and core self-evaluations on organizational citizenship behavior: the role of psychological empowerment as a partial mediator", Leadership and Organization Development Journal, Vol. 38 No. 3, pp. 463-481.

Jose, G. and Mampilly, S.R. (2014), "Psychological empowerment as a predictor of employee engagement: an empirical attestation”, Global Business Review, Vol. 15 No. 1, pp. 93-104.

Kaur, P., Malhotra, K. and Sharma, S.K. (2020), "Moderation-mediation framework connecting internal branding, affective commitment, employee engagement and job satisfaction: an empirical study of BPO employees in Indian context”, Asia-Pacific Journal of Business Administration, Vol. 12 Nos 3-4, pp. 327-348.

Kelidbari, H.R.R., Fadaei, M. and Ebrahimi, P. (2016), "The role of ethical leadership on employee performance in Guilan University of medical sciences", Procedia-Social and Behavioral Sciences, Vol. 230, pp. 463-470.

Khajeheian, D. and Ebrahimi, P. (2021), "Media branding and value co-creation: effect of user participation in social media of newsmedia on attitudinal and behavioural loyalty", European Journal of International Management, Vol. 16 No. 3, doi: 10.1504/EJIM.2020.10020735.

Kim, S.H., Kim, M.S. and Lee, D.H. (2016), "The effects of personality traits and congruity on customer satisfaction and brand loyalty: evidence from coffee shop customers", Advances in Hospitality and Leisure, Emerald Group Publishing Limited, pp. 3-33.

Kimpakorn, N. and Tocquer, G. (2010), "Service brand equity and employee brand commitment", Journal of Services Marketing, Vol. 24 No. 5, pp. 378-388.

King, C. and Grace, D. (2008), "Internal branding: exploring the employee's perspective", Journal of Brand Management, Vol. 15 No. 5, pp. 358-372.

Kirrane, M., Kilroy, S. and O'Connor, C. (2019), "The moderating effect of team psychological empowerment on the relationship between abusive supervision and engagement", Leadership and Organization Development Journal, Vol. 40 No. 1, pp. 31-44, doi: 10.1108/LODJ-07-2018-0252.

Kundu, S.C., Kumar, S. and Gahlawat, N. (2019), "Empowering leadership and job performance: mediating role of psychological empowerment", Management Research Review, Vol. 42 No. 5, pp. 605-624, doi: 10.1108/MRR-04-2018-0183.

Laschinger, H.K.S., Finegan, J., Shamian, J. and Wilk, P. (2001), "Impact of structural and psychological empowerment on job strain in nursing work settings: expanding Kanter's model", JONA: The Journal of Nursing Administration, Vol. 31 No. 5, pp. 260-272.

Lee, A.N. and Nie, Y. (2014), "Understanding teacher empowerment: teachers' perceptions of principal's and immediate supervisor's empowering behaviours, psychological empowerment and work-related outcomes", Teaching and Teacher Education, Vol. 41, pp. 67-79.

Lee, J., Park, S.Y., Baek, I. and Lee, C.S. (2008), "The impact of the brand management system on brand performance in B-B and B-C environments", Industrial Marketing Management, Vol. 37 No. 7 , pp. 848-855.

Li, Y., Wei, F., Ren, S. and Di, Y. (2015), "Locus of control, psychological empowerment and intrinsic motivation relation to performance", Journal of Managerial Psychology, Vol. 30 No. 4, pp. $422-438$.

Liden, R.C., Wayne, S.J. and Sparrowe, R.T. (2000), "An examination of the mediating role of psychological empowerment on the relations between the job, interpersonal relationships, and work outcomes", Journal of Applied Psychology, Vol. 85 No. 3, p. 407.

Mansoor, S. and Ali, M. (2020), "Transformational leadership and employee outcomes: the mediating role of psychological empowerment”, Leadership and Organization Development Journal, Vol. 42 No. 1, pp. 130-143.

Matanda, M.J. and Ndubisi, N.O. (2013), "Internal marketing, internal branding, and organisational outcomes: the moderating role of perceived goal congruence", Journal of Marketing Management, Vol. 29 Nos 9-10, pp. 1030-1055.

\section{The effect of internal branding}


Maynard, M.T., Luciano, M.M., D’Innocenzo, L., Mathieu, J.E. and Dean, M.D. (2014), "Modeling timelagged reciprocal psychological empowerment-performance relationships", Journal of Applied Psychology, Vol. 99 No. 6, p. 1244.

Mehari, D. and Aemiro, T. (2013), "Firm specific factors that determine insurance companies' performance in ethiopia”, European Scientific Journal, Vol. 9 No. 10, pp. 245-255.

Moghadamzadeh, A., Ebrahimi, P., Radfard, S., Salamzadeh, A. and Khajeheian, D. (2020), "Investigating the role of customer Co-creation behavior on social media platforms in rendering innovative services", Sustainability, Vol. 12 No. 17, doi: 10.3390/su12176926.

Mostafa, A.M.S. (2017), "The mediating role of positive affect on the relationship between psychological empowerment and employee outcomes", Evidence-based HRM: a Global Forum for Empirical Scholarship, Emerald Publishing Limited.

Özçelik, G. (2015), "Engagement and retention of the millennial generation in the workplace through internal branding", International Journal of Business and Management, Vol. 10 No. 3, p. 99.

Park, J., Lee, H. and Kim, C. (2014), "Corporate social responsibilities, consumer trust and corporate reputation: South Korean consumers' perspectives”, Journal of Business Research, Vol. 67 No. 3, pp. 295-302.

Patterson, M.G., West, M.A. and Wall, T.D. (2004), "Integrated manufacturing, empowerment, and company performance", Journal of Organizational Behavior: The International Journal of Industrial, Occupational and Organisational Psychology and Behavior, Vol. 25 No. 5, pp. 641-665.

Pereira, J., Braga, V., Correia, A. and Salamzadeh, A. (2021), "Unboxing organisational complexity: how does it affect business performance during the COVID-19 pandemic?", Journal of Entrepreneurship and Public Policy, Vol. 10 No. 3, pp. 424-444.

Pigeon, M., Montani, F. and Boudrias, J.-S. (2017), "How do empowering conditions lead to empowered behaviours? Test of a mediation model", Journal of Managerial Psychology, Vol. 32 No. 5, pp. 357-372.

Punjaisri, K., Evanschitzky, H. and Wilson, A. (2009), "Internal branding: an enabler of employees' brand-supporting behaviours", Journal of Service Management, Vol. 20 No. 2, pp. 209-226, doi: $10.1108 / 09564230910952780$.

Punjaisri, K. and Wilson, A. (2011), "Internal branding process: key mechanisms, outcomes and moderating factors", European Journal of Marketing, Vol. 45 Nos 9/10, pp. 1521-1537, doi: 10. 1108/03090561111151871.

Punjaisri, K. and Wilson, A. (2017), "The role of internal branding in the delivery of employee brand promise", Advances in Corporate Branding, Springer, pp. 91-108.

Ringle, C.M., Wende, S. and Becker, J.M. (2015), SmartPLS 3, SmartPLS GmbH, Boenningstedt.

Roshandel-Arbatani, T., Kawamorita, H., Ghanbary, S. and Ebrahimi, P. (2019), "Modelling media entrepreneurship in social media: SEM and MLP-ANN approach", AD-minister, No. 34, pp. 35-57.

Rosseel, Y. (2012), "Lavaan: an R package for structural equation modeling and more. Version 0.5-12 (BETA)", Journal of Statistical Software, Vol. 48 No. 2, pp. 1-36.

Salamzadeh, A., Kesim, H.K. and Salamzadeh, Y. (2016), "Entrepreneurial universities and branding: a conceptual model proposal", World Review of Science, Technology and Sustainable Development, Vol. 12 No. 4, pp. 300-315.

Sanchez, G. (2013), PLS Path Modeling with R, Trowchez Editions, Berkeley, Vol. 383, p. 2013.

Santos-Vijande, M.L., del Río-Lanza, A.B., Suárez-Álvarez, L. and Díaz-Martín, A.M. (2013), "The brand management system and service firm competitiveness", Journal of Business Research, Vol. 66 No. 2, pp. 148-157.

Seibert, S.E., Wang, G. and Courtright, S.H. (2011), “Antecedents and consequences of psychological and team empowerment in organisations: a meta-analytic review", Journal of Applied Psychology, Vol. 96 No. 5, p. 981. 
Shah, T.A., Khattak, M.N., Zolin, R. and Shah, S.Z.A. (2019), "Psychological empowerment and employee attitudinal outcomes", Management Research Review, Vol. 42 No. 7, pp. 797-817, doi: 10.1108/MRR-05-2018-0194.

Sharma, A., Jadi, D.M. and Ward, D. (2018), "Evaluating financial performance of insurance companies using rating transition matrices", The Journal of Economic Asymmetries, Vol. 18, p. e00102.

Singh, S.K. and Singh, A.P. (2019), "Interplay of organisational justice, psychological empowerment, organisational citizenship behavior, and job satisfaction in the context of circular economy", Management Decision, Vol. 57 No. 4, pp. 937-952.

Smith, T., Capitulo, K.L., Quinn Griffin, M.T. and Fitzpatrick, J.J. (2012), "Structural empowerment and anticipated turnover among behavioural health nurses", Journal of Nursing Management, Vol. 20 No. 5, pp. 679-684.

Soleimani, M., Ebrahimi, P. and Fekete-Farkasne, M. (2021), "The impact of corporate social responsibility dimensions on brand-related consequences with the mediating role of corporate branding-a case study from the iranian insurance sector", Forum Scientiae Oeconomia, Vol. 9 No. 3, pp. 73-88.

Sujchaphong, N., Nguyen, B. and Melewar, T. (2015), "Internal branding in universities and the lessons learnt from the past: the significance of employee brand support and transformational leadership", Journal of Marketing for Higher Education, Vol. 25 No. 2, pp. 204-237.

Tajpour, M., Hosseini, E. and Salamzadeh, A. (2020), "The effect of innovation components on organisational performance: case of the governorate of Golestan Province", International Journal of Public Sector Performance Management, Vol. 6 No. 6, pp. 817-830.

Tuominen, S., Hirvonen, S., Reijonen, H. and Laukkanen, T. (2016), "The internal branding process and financial performance in service companies: an examination of the required steps", Journal of Brand Management, Vol. 23 No. 3, pp. 306-326.

Wang, Y.C., Yang, J. and Yang, C.E. (2019), "Hotel internal branding: a participatory action study with a case hotel", Journal of Hospitality and Tourism Management, Vol. 40, pp. 31-39.

Yao, Q., Chen, R. and Cai, G. (2013), "How internal marketing can cultivate psychological empowerment and enhance employee performance", Social Behavior and Personality: An International Journal, Vol. 41 No. 4, pp. 529-537.

Yesil, S. and Kaya, A. (2013), "The effect of organisational culture on firm financial performance: evidence from a developing country", Procedia-Social and Behavioral Sciences, Vol. 81, pp. 428-437.

Zhang, H. and Xu, H. (2021), "Improving internal branding outcomes through employees' selfleadership”, Journal of Hospitality and Tourism Management, Vol. 46, pp. 257-266.

\section{About the authors}

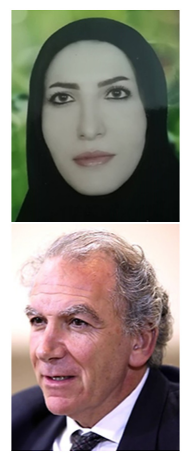

Maryam Soleimani is currently an assistant professor of management, economics and accounting at the Payame Noor University of Tehran, Iran. She has a PhD in Strategic Management. Her research is mainly focused on entrepreneurship, marketing and Social Media. She is an expert in quantitative analysis with various software (Amos Graphic/Lisrel/SPSS/SmartPLS 3/Meta-analysis with CMA 2/ PLS-R). She has had published papers in international journals in management.

Leo Paul Dana is a professor at Dalhousie University. He is also a member of the Entrepreneurship and Innovation Chair, which is part of LabEx Entreprendre at the Universite de Montpellier. A graduate of McGill University and HEC-Montreal, he has served as Marie Curie Fellow at Princeton University and Visiting Professor at INSEAD. He has published extensively in a variety of journals, including Entrepreneurship: Theory and Practice, International Business Review, International Small Business Journal, Journal of Business Research, Journal of Small Business Management, Journal of World Business, Small Business Economics and Technological Forecasting and Social Change.

\section{The effect of internal branding}




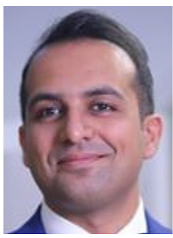

Aidin Salamzadeh is an assistant professor at the University of Tehran. His interests are startups, new venture creation and entrepreneurship. Aidin serves as an associate editor in "Revista de Gestão", "Innovation and Management Review" (Emerald), "Entrepreneurial Business and Economics Review", "Journal of Women's Entrepreneurship and Education" as well as an editorial advisory in "The Bottom Line" (Emerald). Besides, he is a reviewer in numerous distinguished international journals. He is the co-founder of the Innovation and Entrepreneurship Research Lab (UK), and a reviewer in numerous distinguished international journals. Aidin is a member of the European SPES Forum, the Asian Academy of Management and Ondokuz Mayis University. Aidin Salamzadeh is the corresponding author and can be contacted at: salamzadeh@ut.ac.ir

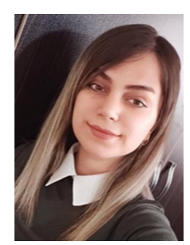

Parisa Bouzari is a researcher in managerial studies, especially supply chain management and digital marketing. She is one of the authors of the book chapter titled "The interaction between human and media in the future of banking industry" in the Book of "Contemporary Applications of the Actor-Network Theory". Palgrave McMillan (A part of Springer Nature). She is an expert in data collection and surveys.

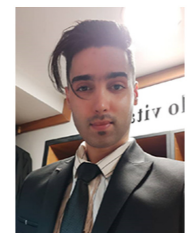

Pejman Ebrahimi is a researcher and member of Iran's Elite. He is a $\mathrm{PhD}$ candidate at MATE university of Hungary. Moreover, Pejman is an educator and expert in statistical analysis (Programming with Python/ Machine learning by jupyter/Data science/Statistical analysis with Amos Graphic/SPSS/SmartPLS 3/Econometrics with Eviews and STATA/EQS/SAS/R/R Studio/Nvivo/Minitab/Meta-analysis with CMA 2 and STATA/DEA with MATLAB/DEMATEL with MATLAB/ ANN with MATLAB/ IBM SPSS Modeler/Future study with Cross Impact Analysis and MICMAC software/ ANN with super decision/AHP with expert choice/Grounded theory with Atlas ti) and microeconomics as his main areas of interest. He is interested in green entrepreneurship, green innovation, SME performance, social media marketing, social networks marketing and financial performance. Pejman has been the author of numerous marketing papers with quantitative and qualitative analyses approaches in international conferences and journals. He is also a reviewer of some international journals in management and economics and the author of some books.

For instructions on how to order reprints of this article, please visit our website:

www.emeraldgrouppublishing.com/licensing/reprints.htm

Or contact us for further details: permissions@emeraldinsight.com 